\title{
INFORMATIKAI KUTATÁS A GERINCSEBÉSZETBEN
}

\section{INFORMATIC RESEARCH IN SPINE SURGERY}

\author{
Kocsis Zoltán Tamás ${ }^{1^{*}}$, Dr. Kovács János ${ }^{2}$ \\ 1,2 Informatika Tanszék, Gépészmérnöki, Informatikai és Villamosmérnöki Kar, Széchenyi István Egyetem, \\ Magyarország \\ https://doi.org/10.47833/2020.2.CSC.002
}

\section{Kulcsszavak: \\ DICOM \\ Orvosdiagnosztikai képek \\ Gerincmütét \\ Képfeldolgozás}

\section{Keywords:}

DICOM

Medical imaging

Spine surgery

image processing

\section{Cikktörténet:}

Beérkezett 2020. április 30.

Átdolgozva 2020. május 19.

Elfogadva 2020. május 25.

\footnotetext{
* Kapcsolattartó szerző. Tel.: +36 (96) 613-652

E-mail cím: kocsis.zoltan@ga.sze.hu
}

\section{Összefoglalás}

Az informatika olyan fejlödésen ment keresztül, melynek köszönhetöen jelen van az orvostudományban is. $A z$ orvosdiagnosztikai képek nem csak a betegségek, csonttörések diagnosztizálására, alkalmasak, hanem akár egy mütét előkészítésére is. A képalkotó orvosdiagnosztikai eljárások segítik az operatört a mütét lebonyolitásában is. Ennek ellenére a gerincmütétek során mégis előfordulnak olyan orvosi hibák, amelyek a betegek újra mütését is szükségessé tehetik. Kutatás során arra keresünk választ, hogy milyen módon lehet az informatika módszereivel segíteni a gerincmütéteket végzö orvos munkáját, Javaslatunk egy erre a célra épített gerincmütéti robot, amely a képi diagnosztika alapján az általunk kidolgozott matematikai algoritmussal elvégzi a mütét szempontjából kritikus csavarbeültetési pontok paramétereinek meghatározását és előkészitését. A cikk bemutatja a kutatás indíttatását és azt az eljárást, amely alapján sikerült az orvosdiagnosztikai képeket feldolgozni, illetve a módszert, amellyel ezeket az adatokat továbbitani lehet a robotnak.

\section{Abstract}

Informatics has undergone a development that has made it present in medicine as well. Medical diagnostic images are not only suitable for diagnosing diseases and bone fractures, but also for the preparation of a surgery. Imaging medical diagnostic procedures also help the operator perform the surgery. Nevertheless, medical errors do occur during spinal surgeries that may lead to the reoperation of patients. In the course of our research we are looking for a solution how IT methods can help the work of a doctor performing spinal surgeries. We propose a purpose-built spinal surgery robot that can define and prepare the parameters of the screw implantation point with the help of the image diagnostics and a special mathematical algorithm designed by us. The article describes the initiation of the research and the procedure by which the medical diagnostic images were processed and the method by which this data can be transmitted to the robot.. 


\section{Bevezetés}

Az elmúlt évek technikai fejlödésének köszönhetően számos tudományág összekapcsolódhatott. Ez a folyamat gyakorlatilag a XX. sz. elején indult el, ennek eredményeként jöttek létre az un. interdiszciplináris tudományok, így az informatika is. Az egyik ilyen tudomány az informatika, ami már szinte az élet minden területén megtalálható, és az orvostudományokban is egyre jelentősebb szerepet játszik. Mai szemmel nézve már megszokott, hogy a kórházakban, rendelökben például a páciensek kórtörténeti adatait számítógépen tárolják. Az adatok tárolásán túlmenően számos olyan terület létezik az orvostudományban, ahol az informatikai eszközök és módszerek alkalmazása jelentősen segíti a munkát. Az egyik ilyen terület az un. képalkotó diagnosztika.

Mindenki számára ismeretes a röntgenfelvétel, amelyet régebben egy fólián előhívva kaptak kézhez az orvosok a diagnosztika elvégzéséhez vagy egy mütét előkészítéséhez. A radiológia ma már nem csak a röntgenkészülékeket jelenti, megjelentek új, korszerübb eszközök. Így pl. a gerincsebészetben is alkalmazott Compuer Tomográfia (CT), illetve a Mágneses Rezonancia (MR) vizsgálatok. [1] Az így készült felvételeknek az egyik előnye a röntgenfelvételhez képest, hogy felvételsorozatokat tudunk készíteni. Ezek a felvételek megfelelő szoftverek segítségével egymásra építhetők, aminek köszönhetően nem csupán kettő, hanem három dimenzióban is képesek vagyunk megfigyelni a vizsgálandó testrészt. Jelenleg az orvosok ezzel a háromdimenziós technikával készítik elő, majd ellenőrzik a mütétet.

A számítógép ma már több módon is képes az embert segíteni. Számítógéppel támogatott müveletek sokkal pontosabbak, mint azok, amelyeket az ember szabad kézzel végez. A mütétet végző orvos - mivel nem egy gép - nem tudja minden alkalommal ugyanúgy, ugyanolyan pontosan elvégezni az adott mütétet. Gerincsebészet során amikor a csigolyán végez műtétet, a saját tapasztalatára és szakértelmére van bízva a mütét sikeressége. A siker attól is függ, hogy az a csavar, amit a mütét során el kell helyezni, mennyire pontosan kerül a helyére. A csigolyán az ember nem képes átlátni, viszont az előzőleg készített CT-felvétel alapján a mütét megtervezhető.

Ezek alapján a kutatás egy olyan algoritmus kidolgozására indult, melynek segítségével a műtét pontosan megtervezhető, így számos adatot szolgáltat az orvos számára. A kapott adatokból az orvos eldöntheti, hogy a mütétet ezek alapján elvégzi vagy módosít rajta. Ezek az adatok azonban továbbíthatók egy erre a célra fejlesztendő robot számára. A cikkben röviden bemutatásra kerül a megoldandó feladat, valamint az, hogyan sikerült a mütétet támogató algoritmust kidolgozni.

\section{Gerincsebészeti műtét informatikai támogatása}

\subsection{A gerincsebészeti mütét}

Mielött bemutatnánk a kidogozott algoritmust, szükséges megismerni magát a mütétet, amelyet az informatika segítségével szeretnénk támogatni. Az ember gerincét akkor indokolt müteni, ha valamilyen sérülés érte vagy valamitöl deformálódott [2]. Az orvosok a mütét során a páciens több gerinccsigolyájába - a deformitás fixálása érdekében - csavarokat helyeznek el. A legnagyobb probléma a csavar (1. ábra) helyes elhelyezése, amit a csigolyaívbe latin nevén a Pediculus-ba vezetik be. $A z$ 1. ábrán megfigyelhetö, hogy nem sok hely van, mindössze csak 4-7 $\mathrm{mm}$ áll rendelkezésre. A beavatkozást végző orvosnak leginkább arra kell törekedni, hogy a csavart a csigolyaív középre tudja tenni, mert, ha ez nem sikerül, akkor annak súlyos következményei lehetnek, gyakran előfordul, hogy a páciens újra meg kell müteni. Ezt csökkentendő került kidolgozásra egy gerincmütétet támogató algoritmus. 


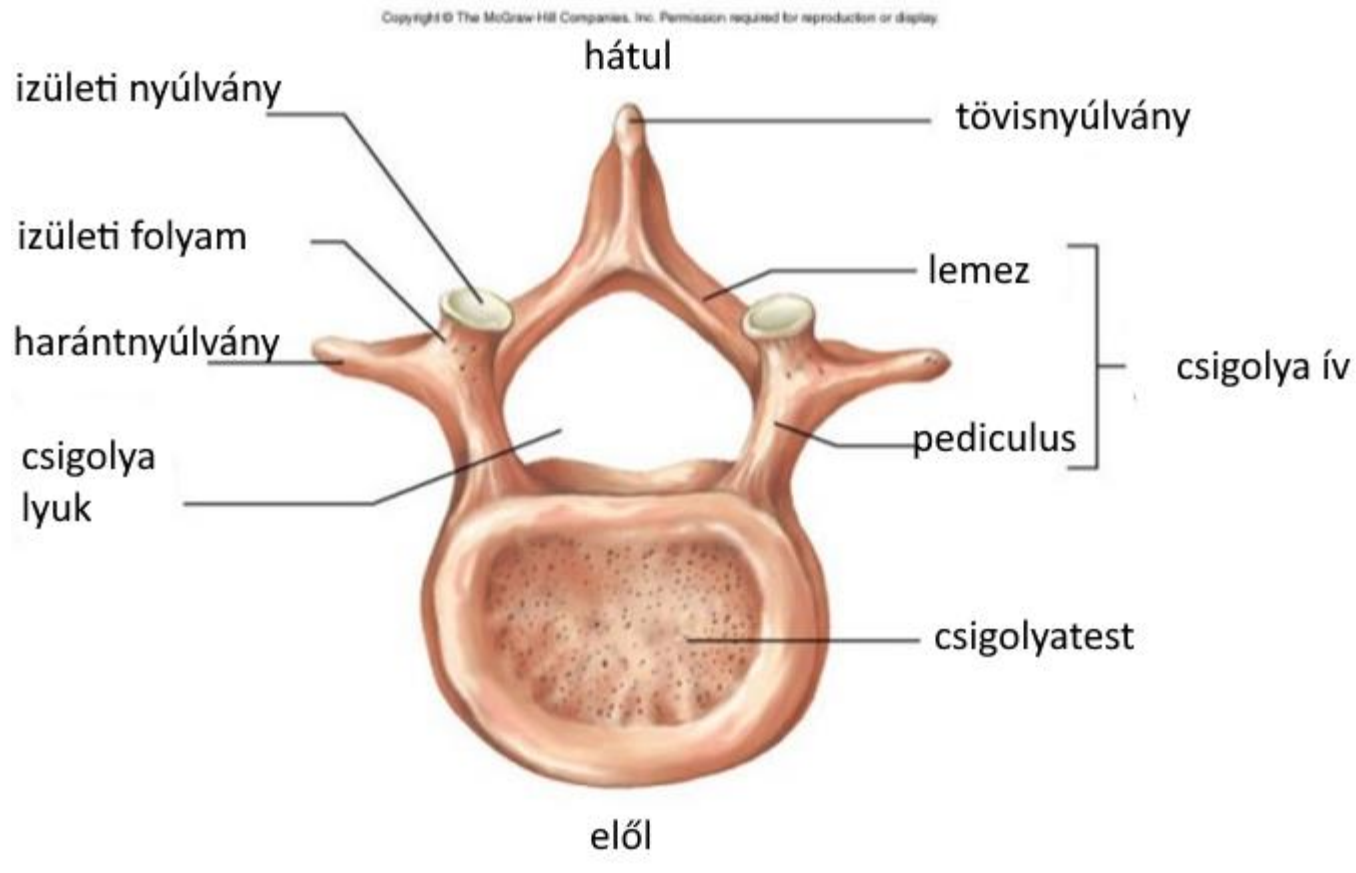

felső nézet

1. ábra Gerinccsigolya anatómiája Forrás: Internet[2018]

\subsection{Orvosdiagnosztikai képek}

Az orvosdiagnosztikai képek számítógépen történő tárolására kidolgoztak egy nemzetközi szabványt. A Digital Imaging and COmmunications in Medicine (DICOM) szabvány, amely lényegében egy összefoglaló szabványgyűjtemény, ami rögzíti az orvosi képalkotó módszerek által digitális formában előállítandó képformátumot, valamint a képalkotás során előálló információk kezelésére, tárolására továbbítására vonatkozó előírásokat. [3] Az eljárások során természetesen lényegesen több adat áll elő és tárolódik, mint amennyit a munka során fel kell használni.

Az első lépés tehát a mütét megtervezéshez szükséges adatok körének maghatározása volt.

\subsection{A megvalósított algoritmus}

A kutatás célja az volt, hogy a mütétet pontosítani, a veszélyeket csökkenteni lehessen. A mütét tervezése mindig egy CT-felvétel készítésével kezdődik. Ezt a képet dolgozzuk fel a számítógép segítségével a mütét megtervezéséhez szükséges információk megszerzése érdekében.

Az első feladat a diagnosztikai képek beolvasása volt, amin meg kellett keresni a mütéti területet. A DICOM képek önmagukban nem feldolgozhatók, ezért szükséges volt átkonvertálni egy feldolgozható formátumba. Formátumnak a PNG képformátumot választottuk. A feldolgozáshoz az OpenEvilDicom [4] keretrendszert, programozási nyelvnek pedig a C\#-ot választottuk. Az EvilDIcom egy nyílt forráskódú rendszer, amit C\#-hoz fejlesztettek ki. Segítségével a DICOM képek könnyen beolvashatók, és elhelyezhetők egy PictureBoxba, amin már könnyen lehet alkalmazni a képfeldolgozó algoritmusokat. A győri Petz Aladár Megyei Oktató kórházból a kutatási munka céljára rendelkezésre bocsátott DICOM-képek a 512x512-es méretűek. Az első lépés egy olyan orvosi kép beolvasása volt, amin gerinccsigolya látható. Beolvasáskor egy orvosi képeken nem csak a csontok, hanem a lágyszövetek is látszanak. Megfelelő beállítással azonban elérhető, hogy csak a kívánt rész, vagyis jelen esetben a csont látszódon. Miután sikerült elérni azt, hogy csak csigolya legyen látható a képen, meg kell tudni határozni a csigolya helyzetét. Erre azért van szükség, mert minden adatot, ami a mütéthez szükséges, innen tudunk kinyerni. Ehhez a feladathoz volt szükséges a számítógépes képfeldolgozás. 
Számos OpenSource keretrendszer létezik erre a célra, ezek közül az EmguCv rendszert választottuk. [5] Ennek segítségével tudjuk meghatározni a csigolya kontúrvonalát, amelyet ha megtaláltunk, akkor a mütéthez szükséges adatok nagy része kinyerhető. A kontúr megtalálásához elöször szükség volt a CT window/level értékének megváltoztatására. Ez a beállítás úgy viselkedik, mint egy hagyományos fényképen a fényerő/kontraszt értékpár. Segítségével el lehet érni, hogy a vizsgálandó képen a csont lágyszövetek nélkül látszódjon. Ezután a diagnosztikai képen már csak fekete és fehér területek látszódnak. A fehér terület adja a gerinccsigolyát. Az EmguCv keretrendszer tartalmaz egy olyan algoritmust, amely megfelelő beállításokkal megkeresi a kontúrt kiadó területeket, jelen esetben a gerinccsigolyát. Ezt szükséges volt kirajzolni a csigolya ismeretes pontjai meghatározása érdekében.

Azt feltételezhetjük, hogy ha a gerinccsigolya közepét sikerül megtalálni, akkor a mütéti pontok meghatározása könnyebbé válik. Ehhez egy - úgymond - célkeresztet rajzoltunk a csigolyába, amit a csigolya szélső pontjai meghatározásával lehet elérni. A csigolya szélső pontjait a már meghatározott kontúr adja. Ebben az esetben a kontúrnak van 4 maximum pontja. Ezeket a pontokat az algoritmus egy maximum határozza meg. A kontúrpontoknak a helye ismeretes a képen, így ebből megtalálható a legmagasabb pont, ami a csigolya teteje, a legalacsonyabb pont, ami a csigolya alja, és ugyanígy a csigolya jobb és bal pontja. Ezeknek a pontoknak ismeretes az $x$ és $y$ koordinátája, ezekböl a pontokból keresendő a csigolya középső pontja. Ezen a ponton keresztül kell húzni egy egyenest, melynek a két végét a jobb és a bal oldali pontok adják. Feltételezhető, hogy ha a felső és az alsó pontot megfelezem, akkor a keresett pontot megkapom, azonban ez nem igaz. Orvosokkal egyeztetve sikerült meghatározni a középső pontot. A pont körülbelül a csigolyatest tetejétől számított $40 \mathrm{~mm}$-re helyezkedik el. Mivel az $x$ koordináta ismeretes volt a szélső pontok meghatározása révén, így a csigolyatest felső y koordinátájából kivonva 40mm-ert kaptuk meg a középső pont mindkét koordinátáját. Ezen a ponton keresztül húzva az egyenest kaptuk meg a kereszt vízszintes vonalát. A 2. ábrán látható, hogy ez a vonal metszi mind a két keresendő pediculust.

Ahhoz, hogy egy képböl kinyert adatok segítségével valós információkkal tudjuk dolgozni a képpontokat(pixel) át kell váltani milliméterre. Az átváltásdhoz tudni kell azt, hogy a két képpont hány pixelnyi távolságra helyezkedik el egymástól, valamint az adott kép hány DPI (dot per inch) felbontású. [6] Ez az érték határozza meg az egy inchen elhelyezkedő képpontok mennyiségét, amit megfelelő konverzióval milliméterre váltunk. A megismert módszer és a keresett képpontok segítségével valós mérteket kapunk eredményül.

A pediculust meghatározásához elég volt a vízszintes vonal mentén végigmenni. Biztosak lehetünk benne, hogy ez a vonal négy pontban metszeni fogja a csigolyát. Ez a keresett négy pont adja ki azt a két pediculus pontot, amelyet keresünk. A csavar megfelelő méretének kiválasztásához tudni kell azt, hogy hol a legkisebb a pediculus. Ennél nagyobb csavart nem lehet alkalmazni a mütét során, mivel az a beteg egészségének károsodásához vezethet.
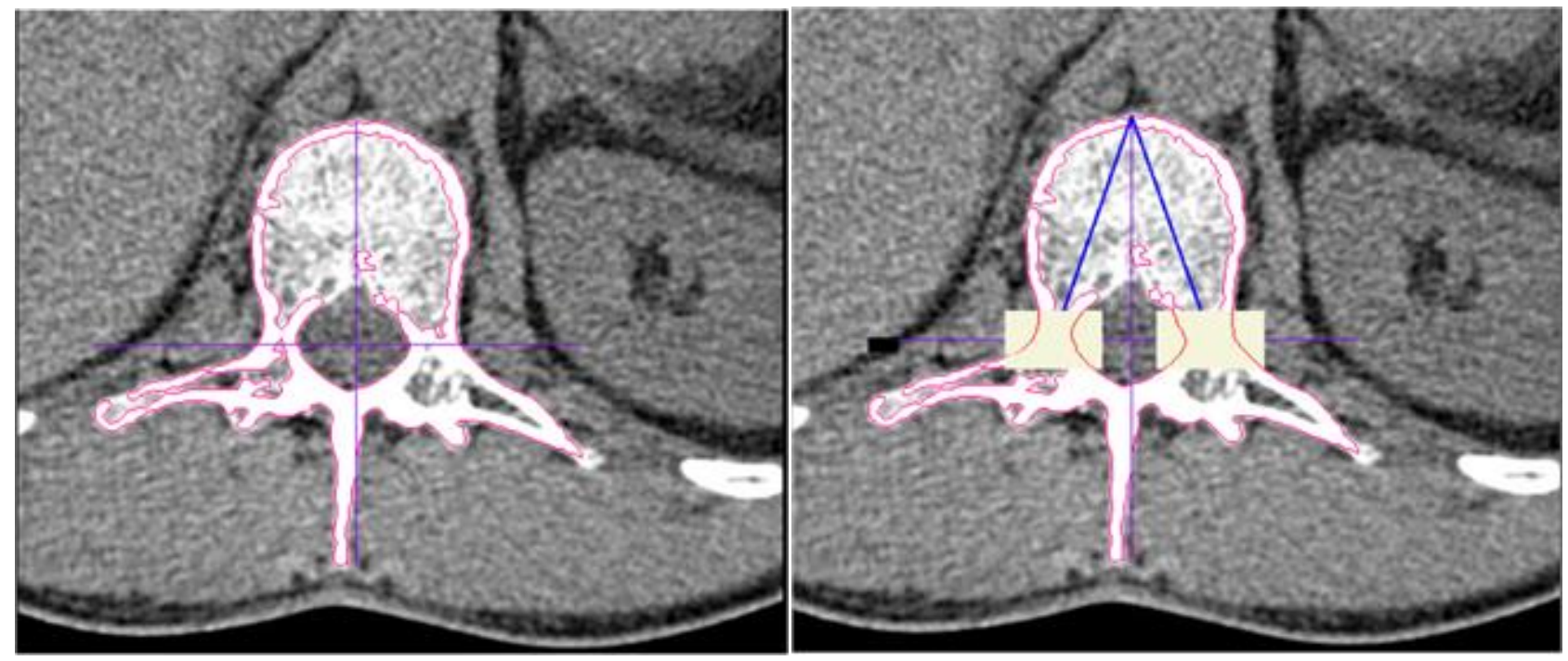

2. ábra A meghatárzott vonalak és a pediculusok 
A vizsgált felvételek tanulmányozása során arra a következtetése jutottunk, hogy a metszéspontoktól minden irányban 5-5 milliméterre adjuk meg a bejárandó területet, ahol megtaláljuk a pediculust alkotó pontokat, melyek közül a minimum távolságot adó két pontot kellett megtalálni. A pontok mindegyike rendelkezik $x$ és $y$ koordinátával. A koordinátageometria segítségével két pont távolsága meghatározható [7], így a jobb, illetve bal oldali pdiculusok minimum pontjai, valamint a keresett méret kiszámítható volt, és megfelelő konverzió után pixel helyett milliméterben kaptuk meg az eredményt. A fúrónak optimális esetben a pediculus közepén kell haladni, ezért szükséges volt a minimum pontok által határolt egyenes középső pontját is meghatározni. A kapott eredmények a 2. ábrán láthatóak. Ez a pont azon kívül, hogy megmondja a középpontot, segítséget nyújt abban is, hogy milyen szögben kell fúrni. A mütét abszolút nulla pontjának tekinthető a csigolya tetejénél található középvonal végpontja. Ehhez viszonyítva meg lehet mondani, hogy milyen távolságra kell mozogni a fúrófejnek, valamint meghatározható fúrás hajlásszöge az optimális mütét elvégzése érdekében. Ezen adatok meghatározásához szintén a koordinátageometria adott segítséget. Meg kell tudni mondani azt is, hogy a fúrófej mikor éri el a csigolyát. Ezt a fenti kiindulópontból a középvonalig terjedő egyenes, valamint a csigolya kontúrvonalának metszéspontjából lehet megmondani. Az általunk használt programozási nyelvben használt függvények egyike sem meg az egyenes pontjainak koordinátáit, ezért szükség volt ezen pontok meghatározására, amit a Bresenham-algoritmus segítségével végeztünk. [8] Az eredmény a 3. ábrán látható.

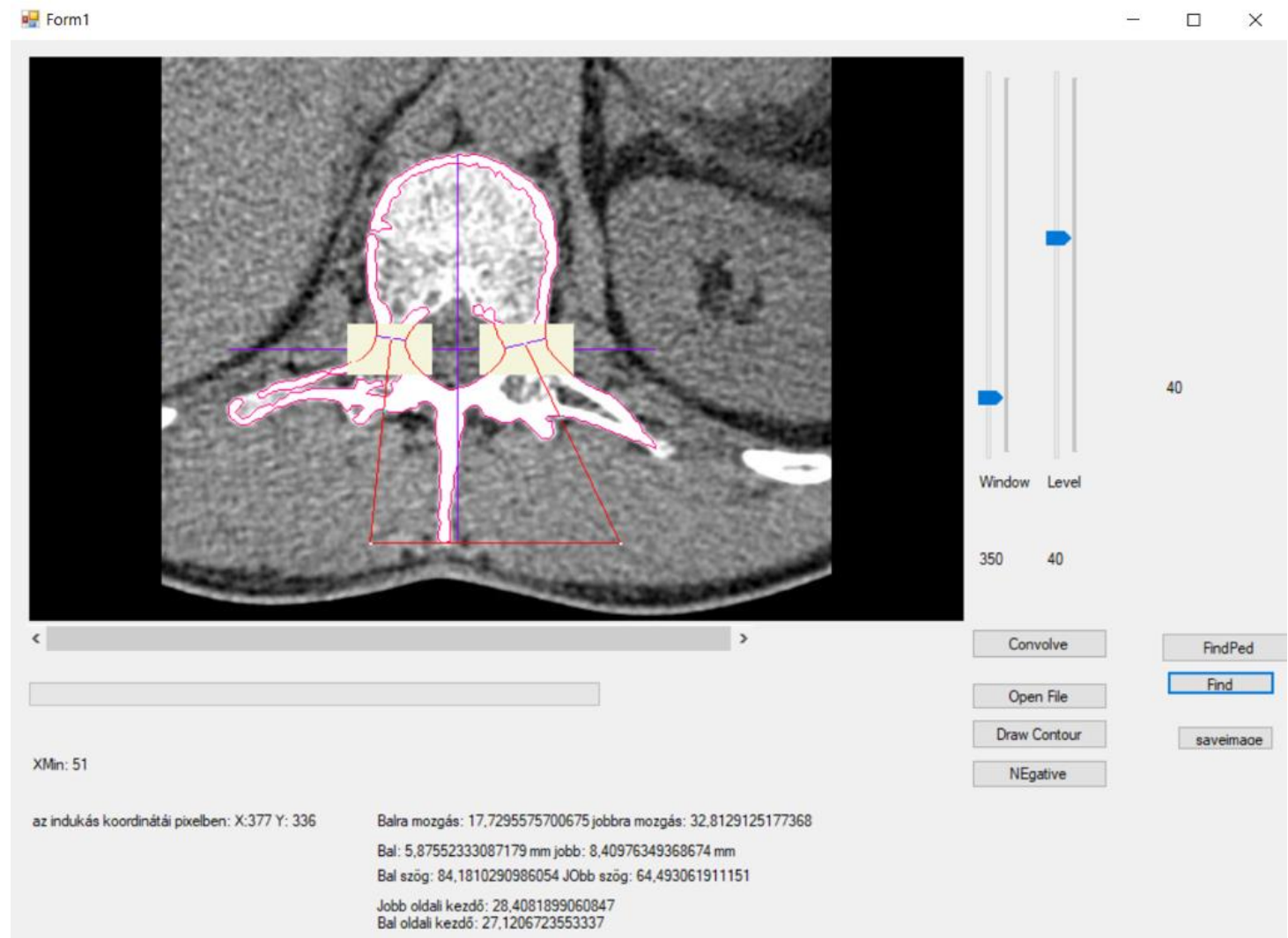

\section{3.ábra a meghatározott eredmények.}

Az így kapott eredmények már kielégítő adatok szolgáltatnak az orvos számára a mütét elvégzéséhez. Mivel az eddigiek csak kétdimenzióban adnak használható adatokat, a mütét sikere érdekében szükség volt a harmadik dimenzió adatinak meghatározására is.

A harmadik dimenzió adatainak meghatározásához a DICOM képek alkalmasak. A DICOM sorozatokban egy saját koordináta-rendszer szerint el van tárolva az egyes képkockák helyzete. A DICOM koordináta rendszer [9] az ember fejétől számítva x,y,z koordinátákat tartalmaz. Az elkészült sorozat első képe tartalmazza a kezdő koordinátát, ahonnan a szeletek készültek, az utolsó eleme pedig a sorozat végkoordinátáját. A sorozat tartalmazza azt is, hogy milyen szeletvastagsággal készültek a képek, ami azt jelenti, hogy hány milliméterenként készült a felvétel a páciensröl. Az 
egyes képszeletek egymása rakásával előállítható a harmadik dimenzió. Nekünk azonban csak arra a függőleges nézetre volt szükség, ahol a csavar középvonala elhalad.

A feldolgozott képröl tudjuk, hogy az a sorozat hányadik képe, valamint azt, hogy a testen belül hol helyezkedik el. Ezeket a figyelembe véve elkészíthető a sorozat függőleges vetülete. Itt az arányok megtartása érdekében figyelni kell a szeletvastagságot, valamint azt is, hogy milyen hosszan helyezkedik el a testben. Ha ezeket nem vesszük figyelembe, akkor torz képet kapunk eredményül, amit nem lehet feldolgozni. A mütéti adatok szempontjából nincs szükség a teljes vetületre, így csak a műtendő csigolya függőleges képét kellett meghatározni. A feldolgozáshoz szintén az előbb bemutatott módszert használtuk. A csigolya vastagságának meghatározására itt már nem volt szükség, azonban azt, hogy milyen irányban és mennyit kell a harmadik dimenzióban elmozdulni, meg kellett határozni, továbbá szükség volt a harmadik dimenzióban beállítandó szögre is. Az eredményül kapott adatok a 4. ábrán láthatóak.

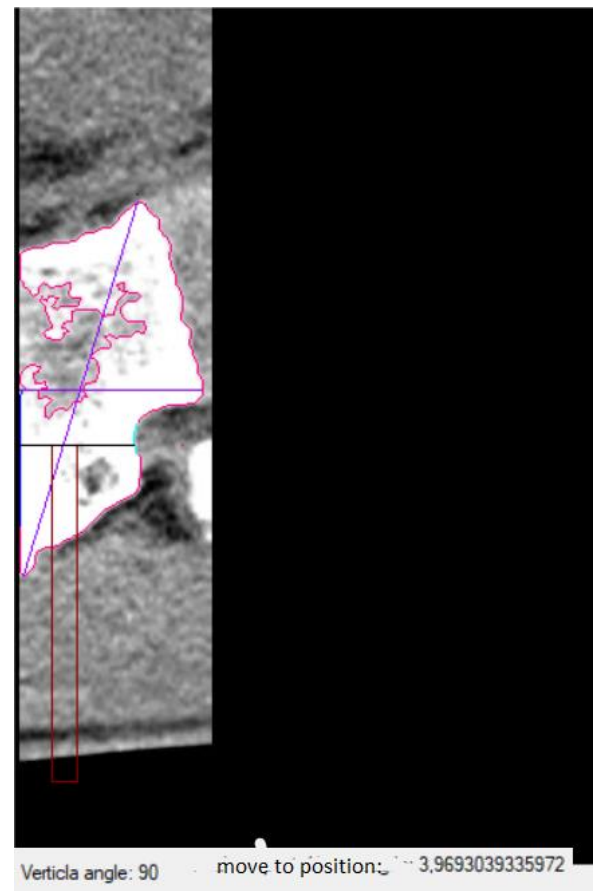

4. ábra a harmadik dimenzió adatai

\section{Eredmények}

A kutatás megkezdése előtt megismertük a gerincsebészeti technikát, valamint az orvosdiagnosztikai képek nemzetközi szabványrendszerét. (DICOM) A megismert orvosdiagnosztikai szabvány alkalmas számos adat közlésére. Ezen adatok közé tartozik a páciens neve, személyes adatai, az orvos neve, valamint olyan adatok, amelyek alkalmasak lehetnek egy mütét előkészítésére. A kifejlesztett algoritmus képes az alapadatokon felül a felismeri a gerinccsigolyát, valamint ennek további elemzésével több, a mütéthez szükséges adatot kinyerni. Az algoritmus képes az orvosdiagnosztikai képsorozatból létrehozni a harmadik dimenzió adatihoz szükséges képet. A harmadik dimenzióból az algoritmus képes a szükséges adatokat elöállítani, így teljeskörü javaslatot tud adni egy mütét lebonyolításához

\section{Következtetés}

A számítógéppel támogatott orvosdiagnosztikai képek nem csak a betegségek diagnosztizálására alkalmasak. A bemutatott algoritmust tovább lehet fejleszteni mesterséges intelligencia alkalmazásával. Eredményül olyan algoritmus nyerhető, amely minimálisra csökkenti a műtéti hibákat. A képekből kinyert adatok nemcsak az orvost segítik, hanem alkalmasak egy gerincsebészeti célra fejlesztett robot számára mütéti adatokat szolgáltani. A robot egy újabb 
kutatási irányt tesz lehetővé. Nem szabad azonban elfelejteni, hogy az emberi élet védelme érdekében a robotok által végzett mütéteknél is szükséges egy tapasztalt orvos jelenléte.

\section{Köszönetnyilvánítás}

A kutatás a GINOP-2.3.4-15-2016-00003 - Felsőoktatási és Ipari Együttmüködési Központ támogatásával készült

\section{Irodalomjegyzék}

[1] Vandulek Csaba, Vinczen Eszter, Rékási Judit, Kürtös Zsófia ,Balogh Orsolya, Szűle Zsuzsanna, Kelemen Kornél, Lukács Lászlóné, Simor Tamás, Képalkotási gyakorlatok az Orvosi Laboratóriumi és Képalkotó Diagnosztikai Analitikus alapszak hallgatói részére, Medicina Könyvkiadó Zrt. Budapest, 2014

[2] Gerincsebészet URL: https://ogk.hu/tevekenyseg/fekvobeteg/gerincsebeszet/ [letöltés dátuma: 2020. 05. 14.]

[3] DICOM Standard URL: https://www.dicomstandard.org/ [letöltés dátuma: 2020:05.14]

[4] EvilDicom: URL: https://github.com/rexcardan/Evil-DICOM [letöltés dátuma: 2020.04.15]

[5] Emgu CV: OpenCV in .NET (C\#, VB, C++ and more) URL: http://www.emgu.com/ [letöltés dátuma: 2020. 05. 14.]

[6] Dr. Hidegkuti Gergely Vinnay Péter, Digitális képalkotás kézikönyv,ViviCom Kiadói és Kommunikációs Kft., 2002.

[7] NagyGábor: Koordinátageometria jegyzetvázlat Elektronikus jegyzet. URL: http://www.math.uszeged.hu/ nagyg/Oktatas/PDF/koordgeo.pdf [letöltés dátuma: 2020. 05. 14.]

[8] Dr. Kovács Emőd: Fejezetek a számítógépi grafikából, Szakanyag KOMA 1995/1-777 pályázat támogatásával Digitális jegyzet. URL: http://files.szt.ektf.hu/dl.php?file=files/Tanári+Megosztások/Kovásznai+Gergely/Bevezetés+a+számítógépi+grafikáb a/jegyzet/KOMA.pdf [letöltés dátuma: 2020. 05. 14.]

[9] Coordinate systems, Slicer Wiki, (2020) : URL: https://www.slicer.org/wiki/Coordinate systems [letöltés dátuma: 2020.04.15] 